\title{
Sahîh-i Buhârî'nin Eksiksiz En Eski Nüshasının Şeyh Alî el-Bistâmî (Musannifek) Eliyle İstanbul’a Getirildiğine Dâir Bazı Şüpheler
}

\section{Ümit Karaver ${ }^{*}$ (1)}

XV. asrında Timurlu/Osmanlı dünyasının önemli şahsiyetlerinden biri olan Şeyh Alî el-Bistâmî Musannifek'in (ö. 875/1470) hayatı ile ilgili bilgilere ${ }^{1}$ dair elimizdeki en önemli kaynak müellifin kendisinin kaleme aldığı, Tuhfetü'l-vüzerâ adlı Farsça eseridir. Müellifin devlet ricâline nasihatlerini içeren eser, vezir Mahmud Paşa'ya ithâf edilmiş, 12 Cemâziyelevvel 861 (7 Nisan 1457) Perşembe günü Edirne'de tamamlanmıştır. Musannifek eserinde; kendisinden, ailesinden, hocalarından, yolculuklarından ve eserlerinden söz etmiştir.

XVI. asırda Taşköprîzâde (ö. 968/1561) eş-Şekāiku'n-Nu 'mâniyye fí 'ulemâi'd-Devleti'l'Osmâniyye adlı eserinde, Musannifek'in Tuhfetül-vüzera'sının otobiyografisi ile ilgili bölümünü ${ }^{2}$ alıntılamış ve bazı eklemeler yapmıştır. Musannifek'e dair bilgilerimiz büyük ölçüde Taşköprîzâde'nin bu eserine dayanmaktadır. Taşköprîzâde'den sonra Mehmed Mecdî Efendi (ö. 999/1591) Hadâiku 'ş-Şekāik adlı eserinde, Cenâbi Efendi, (ö. 999/1590) Târih-i Cenâbî̀sinde, Hoca Sadeddin Efendi (ö. 1008/1599) Tâcü't-tevârih'inde benzer bilgileri tekrar etmişlerdir.

Hiç şüphesiz Taşköprîzâde'nin kendi döneminin imkânlarıyla hazırladığı bu kıymetli eser son derece merkezi bir yerde durmaktadır. Öte yandan Osmanlı ulemasının biyografilerinin verildiği bu eserde Musannifek ile ilgili kaynağı belirtilmeyen bazı rivâyetler de bulunmaktadır. Örneğin Musannifek'in ağzından aktarılan: “Acem ülkesinde bir şeyhle karşılaştı̆̆l, aralarında bir tartışma geçtiği, şeyhin kendisine: 'Yanımda biraz edepsizlik

1 Musannifek'in hayatı ve eserleri ile ilgili bk. Ümit Karaver, Musannifek'e Nisbet Edilen 'Avâmil-i Atîk' Şerhi (Tahkik ve Tahlil) (İstanbul: Kitâbi, 2019), 51-98.

2 Alıntılanan bölüm için bk. Musannifek, Şeyh Alî b. Muhammed el-Bistâmî, Tuhfetü'l-vüzerâ, Topkap1 Sarayı Müzesi Kütüphanesi, Emanet Hazinesi, no. 1342 (Müellif Hattı), vr. 102ª-105ª

\footnotetext{
* Sorumlu Yazar: Ümit Karaver (Dr.), T.C. Diyanet İşleri Başkanlı̆̆ı, Ankara, Türkiye.

E-posta: umitkaraver@hotmail.com ORCID: 0000-0003-0908-8638

https://doi.org/10.26650/di.2019.30.2.0069
} 
ettin, bunun karşıllğ̆ olarak Allah kulağına ağırlık versin, erkek evladın olmasın, neslin kalmasın!'diye beddua ettiği, bu beddua mucebince kulaklarının ağı işitmeye

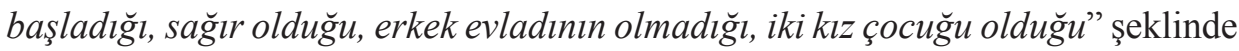
kaynağı belli olmayan bir rivâyet Taşköprîzâde'den itibaren kayıtlara geçmiştir. ${ }^{3}$ Oysa Musannifek, kırkından sonra erkek çocuk sahibi olmuştur. Musannifek, Hidâye şerhinin zahriyesinde oğlu Muhammed b. Şeyh Alî b. Mecdiddîn Muhammed eşŞâhrûdî el-Bistâmî’nin ${ }^{4}$ doğum tarihini "29 Safer 845 (19 Temmuz 1441) Çarşamba kuşluk vakti” şeklinde kendi el yazısıyla kaydetmiştir. ${ }^{5}$ Bu durum, Taşköprîzâde'nin Şekāik'inde yer alan ve kaynağ gerektiğini göstermektedir.

Çağdaş dönemde gördüğümüz bir diğer sorun ise Şekāik' in neşirlerindeki hatalardan kaynaklı yeni tarihî kurgulardır. Bunun en tipik örneği Musannifek'in Konya'dan Bursa'ya geldiği ve burada Sultaniye Medresesi'nde hocalık yaptığı, bu sırada öğrencileri arasında Taşköprîzâde'nin babası Mustafa Efendi’nin olduğu iddiasıdır. Oysa Bursa Sultaniye Medresesi'nde hocalık yapan kişi Musannifek değil Muhyiddin Derviş Muhammed b. Hızır Şah'tır. Şekāik'in Ahmet Subhi Furat tarafindan 1405/1985 senesinde İstanbul'da yapılan tahkikli neşrinde yer alan bir baskı hatasından kaynaklanan bu karışıklığa ${ }^{6}$ Reşat Öngören 2003 y1lında yayımlanan Tarihte Bir Aydın Tarikatı Zeyniler adlı eserinde dikkat çekmişti. ${ }^{7}$ Öngören'in Musannifek'le ilgili Şekāik'teki baskı hatasını tespit etmesine rağmen, başta Türkiye Diyânet İslâm Ansiklopedisi "Musannifek" maddesi ${ }^{8}$ olmak üzere pek çok çalışmada bu hata tekrar edilegelmiştir. Muhtemelen Taşköprîzâde gibi bir

3 Taşköprîzâde, Ebü'l-Hayr İsâmuddîn Ahmed Efendi, eş-Şekāiku'n-Nu'mâniyye fì 'ulemâi'dDevleti'l- 'Osmâniyye (Beyrut: Daru'l-Kitabi'l-Arabî, 1395/1975), 102; Hoca Sadeddin Efendi, Tâcü t-Tevârîh (İstanbul: Tabhane-i Amire, 1279), II: 494.

4 Musannifek, Şerhu'l-Hidâye, Süleymaniye Kütüphanesi, Fâtih, no. 1965 (Müellif Hattı) zahriye.

5 Bk. Musannifek, Şerhu'l-Hidâye, zahriye:

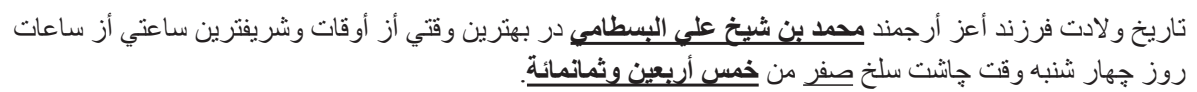

Bu bilgiden beni haberdar eden ve Farsça ibareyi okumamda yardımcı olan, kadim dostum Seyyed Mohammad Taghi Hosseini'ye müteşekkirim.

6 Karşılaştırma için bk. Taşköprîzâde, eş-Şekāiku'n-Nu 'mâniyye fì 'ulemâi'd-devleti'l- 'Osmâniyye, Süleymaniye Kütüphanesi, Hasan Hüsnü Paşa, no. 835M, vr. 53'b-54a; a.mlf., eş-Şekāiku'nNu 'mâniye fì 'ulemâi'd-devleti'l- 'Osmâniyye, thk: Ahmed Subhi Furat, (İstanbul: İstanbul Edebiyat Fakültesi Basımevi, 1405/1985), 167; a.mlf., eş-Şekāiku'n-Nu 'mâniyye fí 'ulemâi'ddevleti'l- 'Osmâniyye (Beyrut: Daru'l-Kitabi'l-Arabî, 1395/1975), 103.

7 Reşat Öngören, Tarihte Bir Aydın Tarikatı Zeyniler (İstanbul: İnsan Yayınları, 2003), 160 (673 numaralı dipnot): "Burada baskı hatası sebebiyle Derviş Mehmed'e ait bilgiler 168. sayfadan başlayıp 167. sayfada devam etmekte ve 169'da son bulmaktadır.” Krş. Taşköprîzâde, eş-Şekāik, 168-167.

8 M. Kâmil Yaşaroğlu, "Musannifek” Türkiye Diyânet Vakfi İslâm Ansiklopedisi (DİA), XXXI, 239. 
otoriteye güvenen araştırmacılar bu bilgilerin kesinliği konusunda şüphe duymayarak benzer ifadeleri tekrar etmiş ve tahkik yolunu tercih etmemişlerdir.

Ülkemizin güzide kurumlarından Türkiye Yazma Eserler Kurumu Başkanlığı ve İslam Araştırmalar Merkezi'nin ortak çalışması sonucu Sahîh-i Buhârr̂̀’nin eksiksiz en eski tarihli nüshasının tıpkıbasımı 2018 yılında İstanbul'da yapıldı ve ilim dünyasının istifadesine sunuldu. ${ }^{9}$ Muhammed Mücîr el-Hatî́b ve Arafat Aydın'ın inceleme yazılarıyla kamuoyuna sunulan bu eserin özellikle inceleme kısmının Musannifek ile ilgili bölümlerinde yukarıda zikrettiğimiz hataların tekrar edildiği ve bazı kesin olmayan bilgilerin kesin bilgiler olarak sunulduğu görülmektedir.

Biz çalışmamızda elimizden geldiği kadar Musannifek'in bizzat kendi kayıtlarından hareketle, tıpkıbasımı yapılan nüshanın inceleme kısmında yer alan musannifle ilgili bilgileri değerlendirerek tashih edilmiş bilgileri zikredeceğiz. Ardından konu ile ilgili bazı soru ve sorunları gündeme getireceğiz.

\section{Sahih-i Buhârî Neşrindeki Musannifek'in Hayatına Dair Bilgilerin Değerlendirilmesi}

İlgili neşirde Sahîh-i Buhârî’nin Murad Molla Kütüphanesi no. 577'deki nüshasının Musannifek ile ilgili temel iddiası nüshanın müellif eliyle vakfedildiğgi ve Endülüs-Mısır-İstanbul üçgeninin son ayağı olan İstanbul'a yine Musannifek tarafından getirildiğidir. Biz eserde dile getirilen iddiaları alıntıladıktan sonra değerlendirmesini yapacağız.

\section{1. "Musannifek, Mahmud Paşa'nın davetiyle İstanbul'a gelmiştir." 10}

Sultan Şahruh'un danışmanlığın $1^{11}$ yapan ve muhtemelen diplomatik misyonlu görevler sebebiyle 840'lı yılların ${ }^{12}$ başından itibaren Anadolu'ya pek çok defa gelip

9 el-Câmi 'u's-Sahîhu'l-Müsnedü'l-Muhtasar Min Hadîsi Rasülillâh Sallâllâhu Aleyhi ve Sellem, Sahîh-i Buhârî (İstanbul: Türkiye Yazma Eserler Kurumu Başkanlığı Yayınları, 2018), Tıpkıbasım, Süleymaniye Yazma Eser Kütüphanesi, Murad Molla, no. 577'de Kayıtlı Nüshanın Tıpkıbasımı, (inceleme-fihrist), inceleme: Muhammed Mücîr el-Hatîb, Arafat Aydın.

10 Sahîh-i Buhârî, tıpkıbasım, 1: 68.

11 Musannifek, Hallü'r-rumûz, Süleymaniye Kütüphanesi, Fâtih, no. 2611, (müellif hatt1) vr. 145a:

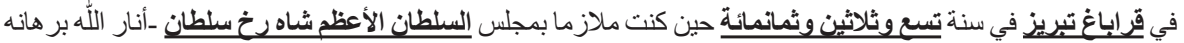

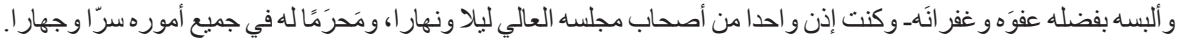

12 Musannifek'in 843/1439'da Konya'da; 845/1442 senesinde Bursa'da olduğuna dair bk. Zemahşerî, el-Keşşâff, Süleymaniye Kütüphanesi, Fâtih no. 386, (zahriye):

من كتب الفقير إلى اللّه الغني شيخ علي بن مجد الدين الثاهرودي ختم اللّه حاله بالحسنى بمقام قونيهُ روم في جمادى الأولى لسنة ثنلاث أربعين وثمانمائة.

Bk. ez-Zeydânî Mazharuddîn Hüseyn b. Mahmud, el-Mefâtîh fi Halli'l-Mesâbîh, Süleymaniye Kütüphanesi, Fatih, no. 5360, vr. $128^{\mathrm{b}}-129^{\mathrm{a}}$ :

لكاتبه شيخ علي البسطامي بمقام برسه رود في شعبان سنة خمس أربعين وثمانمائة. 
giden Musannifek, Şâhruh'un ölümüyle beraber yeni bir himâye arayışına girmiştir. 849-856/1445-1452 seneleri arasında yaklaşık yedi yıl Konya'da kalmıştır. ${ }^{13} 856$ Zilhicce'sinde (Aralık 1452) hac farizasını yerine getirmiş ${ }^{14}$ olan Musannifek, Ramazan 858 'de (Ağustos-Eylül 1454) tekrar Konya Meram'a ${ }^{15}$ gelmiş ve iki yıl daha burada kalmıştır. ${ }^{16}$ Görebildiğimiz kadarıyla arada kesintiler olmakla beraber Musannifek' in, 855-860/1451-1456 seneleri arasında Konya'da kaldığı anlaşılmaktadır.

Muhtemelen 860'ların başında Osmanlı hizmetine giren müellif, 861 yılında (7 Nisan 1457) Edirne'ye ${ }^{17}$ yerleşmiştir. Yaklaşık 5 y1l Edirne'de kalan ${ }^{18}$ müellif, 867 senesinin Receb ayında (Mart/Nisan 1463) Edirne'den Sultan Fâtih'in Bosna Seferine katılmıştır. ${ }^{19}$ 868/1464 senesinde tekrar Edirne'de olduğunu tahmin ettiğimiz ${ }^{20}$ Musannifek, 870 senesinde Hayrabolu' dadır. ${ }^{21}$ Ardından tekrar Edirne'de gördüğümüz Musannifek 875 senesine ${ }^{22}$ kadar Edirne'de kalmıştır. Zikrettiğimiz bu kısa zaman örgüsünden de görüleceği üzere on yıla yakın Konya ve on beş yıla

13 Beğavî Muhyissünne el-Hüseyn b. Mes'ud, Mesâbîhu's-Sünne, Süleymaniye Kütüphanesi, Fâtih, no. 1186, (vikāye).

14 Musannifek' in Kâbe-i Muazzama'yı ziyaret tarihine dair kayıt için bk. Musannifek, Şeyh Ali b. Muhammed eş-Şâhrûdî el-Bistâmî, el-Muhammediye fi 't-tefsir fi tefsiri 'l-Fâtiha (Kitâbü 'ş-Şifâ), Beyazıd Kütüphanesi, Veliyüddin Efendi, no. 261, (Mukaddime).

15 Musannifek, Şeyh Ali b. Muhammed eş-Şâhrûdî el-Bistâmî, Şerhu'l-Lübâb, Süleymaniye Kütüphanesi, Fâtih, no. 5004 (Müellif Hatt1), vr. 725-726a .

16 Zemahşerî, Carullah Mahmud b. Ömer, el-Keşşâf an hakāiki 't-tenzil, Süleymaniye Kütüphanesi, Fâtih, no. 393 (Müstensih: Musannifek, Konya, 860), vr. 247 $-248^{\mathrm{a}}$.

17 Musannifek, Şeyh Ali b. Muhammed eş-Şâhrûdî el-Bistâmî, Tuhfetü'l-vüzera, Süleymaniye Kütüphanesi, Ayasofya, no. 2855, vr. $142^{\text {b }}$.

18 Musannifek, Hallü'r-rumûz, vr. 203a .

19 Süleymaniye Kütüphanesi, Fâtih, no. 1439'da yer alan İbn Hacib'in Muhtasaru 'l-Münteha isimli eserinin nüshası Musannifek' in temellüküdür. Bu nüsha Musannifek tarafından okunmuş, notlar alınmış ve vakfedilmiştir. Nüshanın $100^{\mathrm{b}}$ sayfasında Musannifek' in hattıyla kayıtlı olan notta: در تاريخ سنه سبع وستين در ماه رجب از ادرنه به لنكر رفته شد.

867 Receb ayında (Mart/Nisan 1463) Edirne'den askerle birlikte çıkıldığına dair bir ifade bulunmaktadır. Bu tarih Bosna seferine çıkışının tarihi olabilir.

20 İbn Hâcib Cemaleddîn Osman b. Ömer, Muhtasaru İbn Hâcib fì usûli'l-fikh, Süleymaniye Kütüphanesi, Çorlulu Ali Paşa, no. 169 (Müstensih: Yahya b. Muhammed), vr. 120․ Musannifek' in yeğeni ve talebesi Yahya b. Muhammed, 868 senesinin Ramazan ayı sonlarında (Haziran 1464) İbn Hacib'in muhtasarını, 10 Zilhicce 869/ 3 Ağustos 1465 tarihinde “Dırâmü's-Sakt" adlı eseri Fatih Sultan Mehmed'in mutalaası için Edirne'de istinsah etmiştir. Musannifek'in yeğenini yanından ayırmadığı dikkate alınırsa Musannifek' in bu tarihlerde Edirne'de olma ihtimali vardır.

21 Musannifek, Şerhu'l-Vikāye, vr. 45'.

22 İbn Esir Mecdüddîn Mübarek b. Muhammed, Câmiu'l-usûl min ehâdisi'r-rasul, Süleymaniye Kütüphanesi, Fâtih, no. 722, (zahriye). 
yakın Edirne'de kalan Musannifek'in, Şahrûd, Bistâm, Herat, Karabağ, Tebriz, Meram, Larende, Bursa, Ebher, Erzincan, ${ }^{23}$ Tokat, Dımaşk, Mekke, Medine, Hayrabolu ve Bosna'ya seyahatleri dikkate alındığında İstanbul'a da gelmiş olma ihtimali bulunmaktadır. Ancak Musannifek'in İstanbul'a geldiğine dair bir bilgiye kendi kayıtlarından hareketle henüz ulaşılamamıştır.

Taşköprîzâde'den itibaren kayıtlara geçen Musannifek'in Mahmud Paşa'nın davetiyle İstanbul'a geldiğine dair rivâyetin kaynağı bilinmemektedir. Müellifin günümüze ulaşan notlarından hareketle bu rivâyet henüz doğrulanamamıştır.

2. "Musannifek eserlerini İstanbul Kütüphanelerine veya Sahn-ı Semân medreselerine vakfetmiştir." "24 "Musannifek bu medreselere kitap bağlşlayanlardandır ve Sahn-ı Semân medreselerine bağışladı̆̆ı kitaplardan biri de bugün tıpkıbasımına muvaffak olduğumuz Sahîh-i Buhârî nüshasıdır." 25

Musannifek' in eserlerini Sahn-1 Semân (Semâniye) medreselerine vakfettiğine dâir rivâyet, muhtemelen Mecdî'nin (ö. 999/1591) Hadâikü 'ş-Şekāik adlı eserinin kenar notundaki: "Mervidir ki Mevlana Musannifek Hazretleri mâlik olduğu kitaplarını sahn müderrislerine vakfedip mütalaasını anlara tansis ve tahsis eyledi." şeklindeki kaynağı belli olmayan bir rivâyete dayanmaktadır. ${ }^{26}$ Yukarıda alıntılanan cümlenin içerisindeki "sahn müderrisleri" bazı araştırmacılar tarafından "sahn medreseleri" diye de okunmuştur.

Musannifek'in eserlerini İstanbul Kütüphanelerine veya Sahn-1 Semân (Semaniye) medreselerine vakfettiğine dair Musannifek'in bizzat kendisinden günümüze ulaşan bir kayda henüz rastlanmamıştır. Müellifin günümüze ulaşan vakıf kayıtlarında " $b u$ kitâbı ulemâya ve fudalâya vakfettim" ifadesi geçmekte, Sahn-1 Semân (Semaniye) medreselerine dair bir ibare bulunmamaktadır. Örneğin Musannifek, 871 Receb/1467 Şubat ayında Edirne'de satın aldığı Câmiu's-Sahîh/Sahih-i Buhârî̀nin birinci cildini 873/1468 senesinde şu ifadelerde vakfetmiştir:

"Kerîm olan Allah'ın lütfunu, rızasını, mağfiretini umarak, ben -vakfeden fakir Şeyh Alî b. Mecdiddîn el-Bistâmî- 873 senesinde bu mübarek kitabı ulemaya ve

23 Musannifek'in Erzincan seferi için bk. Hâce Parsa Muhammed b. Muhammed, Faslu'l-Hitâb, Süleymaniye Kütüphanesi, Fâtih no. 2753, vr. 4a:

نزول كاتب ببلدة أرزنجان در وقت توجه بروم در كره هشتم بيست وهشتم جماد الآخر سنة ثمان أربعين وثمانمائة حرره

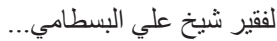

24 Sahîh-i Buhârî, tıpkıbasım, 1: 68.

25 Sahîh-i Buhârî, tıpkıbasım, 1: 70.

26 Bk. Mehmed Mecdî Efendi, Hadâiku'ş-Şekāik, Tercüme ve Zeyl-i Şekāik-i Numâniyye (İstanbul: y.y., 1409/1989) haz. Abdülkadir Özcan, I, 187 (hâmiş). 
fudalaya sahîh şerî‘ bir vakıfla vakfettim." ${ }^{27}$

Musannifek, Sultan Fâtih'e sunmak üzere yazdığı Fâtiha sûresinin bir müsveddesini 864/1460 senesinde yani ölümünden on bir sene evvel Edirne'de vakfetmiştir. ${ }^{28}$ Sahn-1 Semân (Semaniye) Medresesi'nin yapımının 875/1470 senesinde tamamlandığ $1,{ }^{29}$ müellifin bu tarihten çok önce eserlerini vakfetmeye başladığı dikkate alınırsa, eserlerini Edirne'de ulemâya ve fudalâya vakfeden Musannifek'in nüshaları daha sonra Sahn-1 Semân (Semaniye) kütüphanesine nakledilmiş olabilir. Dolayısıyla "Musannifek eserlerini İstanbul Kütüphanelerine veya Sahn-ı Semân Medreselerine vakfetmiştir." şeklinde kesin bir yargıda bulunmak elimizdeki bilgiler ışında mümkün görünmemektedir.

3. "Musannifek eliyle Sahn-ı Semân medreselerine vakfedilmesinden klsa bir süre sonra kütüphanenin hafiz-ı kütübü tarafindan çıkarllan envanter defterinde Musannifek'in vakfettiği kitapların listesi verilmiş..." ${ }^{30}$

Yukarıda Musannifek'in eserlerini Sahn-1 Semân medreselerine vakfettiğine dair bir kayıt olmadığından söz ettik. Ayrıca nüshanın kısa bir süre sonra kütüphanenin envanter defterine kaydedildiği iddiası da tam olarak gerçeği yansıtmamaktadır. Zikri geçen envanter defteri Hacı Hasanzâde'nin (ö. 979/1572) Sahn-1 Semân (Semâniye) medresesinde görevli iken 21 Rabiulahir 968/9 Mart 1561 tarihinde $^{31}$ hazırladığı şu an Topkapı Sarayı Müzesi Arşivi, no. 9559'da (tıpkı basım eserin inceleme kısmında numara hataen 0559 olarak yazılmış) bulunan defterdir. Yani Musannifek' in vefatından doksan üç sene sonra hazırlanmıştır.

Osmanlılardaki kütüphaneler üzerine yaptığı önemli araştırmaları ile bilinen İsmail E. Erünsal'ın ilk olarak varlı̆̆ından söz ettiği, XV. ve XVI. yüzyıla ait dört adet envanter defteri bulunmaktadır. Bunlar, şuan Başbakanlık Osmanlı Arşivi'nde bulunan 907-918/1501-1512 seneleri arasında Muhammed b. Ali el-Fenârî’nin (ö.

27 el-Buhârî, Muhammed b. İsmail b. İbrahim, el-Câmiu’s-Sahîh, Süleymaniye Kütüphanesi, Fatih, no. 1092, zahriye:

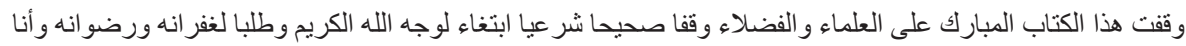

$$
\begin{aligned}
& \text { الو اقف الفقبر شيخ علي بن مجد الدين البسطامي في تاريخ سنة ثلاث وسبعين والثاء وثمانمائة. }
\end{aligned}
$$

28 Bk. Musannifek, Mülteka 'l-bahreyn/Kitâbü'ş-Şifâ, Süleymaniye Kütüphanesi, Fatih, no. 636 (zahriye).

29 İsmail E. Erünsal, “Osmanlllarda Kütüphaneler ve Kütüphanecilik Tarihi Gelişimi ve Organizasyonu (İstanbul: Timaş Yayınları, 2015), 106.

30 Sahîh-i Buhârî, tıpkıbasım, 1: 68.

31 Hacı Hasan-zâde, Fâtih Kütüphanesi Katalogu, Topkapı Sarayı Müzesi Arşivi, no. 9559 (kapak). Kesin tarihin tesbitinde yardımından dolayı Said Kayacı'ya minnettarım. 
929/1522-23) hazırladığ1 defter;32 Fenârî’nin defterini hazırlanırken kullandığ şu an nerede olduğu bilinmeyen asıl defter "Defter-i Atik" ve Hacı Mehmed'in (Molla Arab) defteri; ${ }^{33}$ son olarak yukarıda zikrettiğimiz Hacı Hasan-zâde'nin (ö. 979/1572) hazırladığı defterdir. ${ }^{34}$

Musannifek'in vakfettiği eserlerin zahriyelerinin çoğunda ve Murad Molla Kütüphanesi, no. 577 nüshasinda "حرره الفقير محمد بن علي الفناري" Muhammed b. Ali el-Fenârî imzasıyla varak sayıları kaydedilmiştir. Muhtemelen Muhammed b. Ali el-Fenârî teftiş görevi sırasında eserlerin varaklarını saymış ve kaydetmiştir. Ayrıca Başbakanlık arşivinde bulunan Fenarî’nin hazırladığı defterde Murad Molla Kütüphanesi no. 577 nüshası, Hacı Hasanzade'nin kaydettiği şekilde kayıtlıdır. ${ }^{35}$ Zira Hacı Hasanzâde defterini hazırlarken Fenârî'nin defterinden istifade etmiş oradaki bilgileri aynen aktarmıştır. Fenârî'nin vefat tarihi dikkate alınıp, Musannifek’ten takriben 30 veya 40 sene sonra bu defteri hazırladığı düşünülürse, Fenârî üzerinden de nüshanın kısa bir süre sonra kütüphanenin envanter defterine kaydedildiğini söylemek mümkün görünmemektedir. ${ }^{36}$

Sahn-1 Semân medreselerindeki kitapların kaydedildiği en erken tarihli Defter-i Atik'e ve Hacı Mehmed'in defterine henüz ulaşılamadığından bu nüshanın mezkûr iki defterde kayıtlı olup olmadığını bilemiyoruz. İki deftere ulaşılması durumunda nüsha ile ilgili daha sağlıklı yorumlar mümkün olacaktır. Söz gelimi aşağıda tartışılacak olan, nüshanın içindeki iki eserin ne zaman birleştirildiği, Musannifek'ten ne kadar bir zaman sonra bu birleştirmenin yapıldığı gibi sorulara cevap verilebilecektir.

Yukarıda işaret ettiğimiz üzere Fenârî’nin nüshayı defterine kaydettiği tarih dikkate alınırsa, Musannifek'in ölümü ile Fenârî’nin arasında takriben 30-40 senelik bir zaman diliminde nüshanın durumuna dair bir bilgimiz bulunmamaktadır.

32 Başbakanlık Osmanlı Arşivi (BOA), Bâb-ı Defterî Haremeyn Muhasebesi Sultan Fatih Evkâfı Kalemi Defterleri (Bâb-ı Defterî Haremeyn), 21941-B. Bkz. Erünsal, “Osmanlılarda Kütüphaneler ve Kütüphanecilik, 417-419.

33 Hacı Hasan-zâde, Fâtih Kütüphanesi Katalogu, Topkapı Sarayı Müzesi Arşivi, no. 9559, "Mukaddime"; Erünsal, Osmanlılarda Kütüphaneler ve Kütüphanecilik, 418.

34 Hacı Hasan-zâde, Fâtih Kütüphanesi Katalogu, Topkapı Sarayı Müzesi Arşivi, no. 9559, "Mukaddime". Erünsal, "Osmanlılarda Kütüphaneler ve Kütüphanecilik, 420.

35 Bâb-1 Defterî Haremeyn, 43

36 Musannifek'in şu an Beyazıt Yazma Eser Kütüphanesi, Beyazıt no. 701'de bulunan, kendi telifi ve hattı olan Keşşâf haşiyesi iki envanter defterinde de kayıtlı değildir. Bk. Beyazıt Devlet Kütüphanesi Yazma Eser Adı Kataloğu (İstanbul: Türkiye Diyanet Vakfi İslâm Ansiklopedisi Genel Müdürlüğü, 1990), I, 93 . Katalog bilgisini benimle paylaşan dostum Teymour Morel'e minnettarım. Ayrıca nüshayı görme konusundaki ısrarımı karşılıksız bırakmayan Beyazıt Yazma Eser Kütüphanesi müdürü Salih Şahin’e teşekkür ediyorum. 
Dolaysıyla ilgili neşirde zikredilen, nüshanın kısa bir süre sonra kütüphanenin envanter defterine kaydedildiği bilgisine ihtiyatla yaklaşmak gerekmektedir.

\section{Bazı Soru ve Sorunlar}

Murad Molla, no. 577'de birlikte ciltlenmiş eserlerden biri Abdülazîz Buhari'ye ait olan et-Tahkik adlı eseri; ikinci eser ise neşri yapılan Sahih-i Buhârî adlı kitaptır. Abdülazîz Buhârî'nin et-Tahkik adlı eserinin zahriyesinde Musannifek' in el yazısıyla 847 yılına ait temellük kaydı ve mührü bulunmaktadır. Bu iki eserin ne zaman, nasıl ve neden bir araya getirildiğine dair bir bilgimiz bulunmamaktadır.

Nüshanın vikayesinde yer alan “Bu kitap Mevla merhum Musannifek'in kitaplikta hapsedilmemek şartıyla ehline vakfidır" ${ }^{37}$ şeklindeki yazı, müellifin kendi hattıyla yazdığı eserlerle karşılaştırıldığında anlaşılacağı üzere Musannifek'e ait değildir ve bu yazının kim tarafından ne zaman yazıldığı belli değildir. Bunun ötesinde " $B u$ kitap" ifadesiyle et-Tahkik' in mi yoksa Sahîh-i Buhârî'nin mi kastedildiği de belli değildir. Buna rağmen tıpkıbasımı yapılan eserin girişinde muhtemelen nüshanın Musannifek'e aidiyetini delillendirmek üzere kime ait olduğu ne zaman yazıldığ bilinmeyen bu ifadeler yer almaktadır. ${ }^{38}$

Zahriyesinde nüshanın Musannifek'e aidiyetini kesin olarak gösteren müellifin el yazısının, mührünün ve kenar notlarının olduğu et-Tahkik nüshası tıpkıbasımı yapılan eserde muhtemelen envanter defterinde kayıtlı olmadığı gerekçesiyle yer almamıştır. Nüshanın Musannifek’e ait olduğunun birinci el belgesi niteliğindeki zahriye sayfasının neden çıkarıldığı ve yerine vikâye yaprağında kime ait olduğu bilinmeyen bir ibarenin niçin konulduğu cevaplanması gereken bir sorudur.

İlk sekiz varakta bulunan Musannifek'e ait kenar notlarından hareketle Musannifek tarafindan okunduğu anlaşılan et-Tahkik nüshasının sonundaki reddadesinden devamının olduğu anlaşılmaktadır. Ayrıca dikkatli bir gözle bakıldığında ilk sekiz varağın üzerinde bulunan ve muhtemelen rutubet ve nemden kaynaklı izler Sahîh-i Buhârî nüshasında bulunmamaktadır.

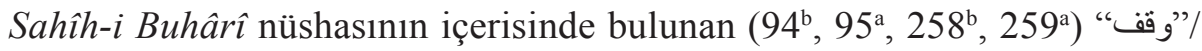
vakf yazıları Musannifek'e ait değildir. Muhtemelen Hafız-1 Kütüpler tarafından yazılmıştır. Fatih koleksiyonunda bulunan Musannifek'e ait olmayan nüshaların üzerinde de bu kayıt bulunmaktadır. ${ }^{39}$

37 Yazının Arapçası şöyledir:

》هذا الكتاب وقف المولى المرحوم مصنفك لمن هو أهله بشرط أن لا يحبس في الخز انة)؛.

38 Sahîh-i Buhârî, tıpkıbasım, vikāye.

39 Benzer bir kaydın olduğu nüsha için bk. Abdülaziz b. Ahmed el-Buhârî, Keşfü'l-esrâr ve hadâiku'l-ebrar, Süleymaniye Kütüphanesi, Fatih, no. 1344, vr. 1'b-2a; $247^{\mathrm{b}}-248^{\mathrm{a}}$. 
Musannifek'in temellükü olan Câmiu 's-Sahîh/Sahîh-i Buhârî̀nin dört nüshası şu an Süleymaniye Kütüphanesi, Fatih, no. 1089, 1090, 1091 ve 1092'de bulunmaktadır. Mezkûr nüshalar Musannifek tarafından okunmuş, notlandırılmış ve 873/1468 tarihinde muhtemelen Edirne'de vakfedilmiştir. Oysa Murad Molla Kütüphanesi, no. 577'de bulunan Câmiu's-Sahîh/Sahîh-i Buhârî'nin (tıpkıbasımı yapılan kısmın) nüshasının üzerinde Musannifek'e ait herhangi bir kayıt bulunmamaktadır.

Bu bilgiler 1şı̆̆ında iki eserin ne zaman birleştirildiği, nasıl ve hangi yolla İstanbul'a geldiği, Musannifek tarafından vakfedilip edilmediği gibi sorulara dair henüz kesin bilgilere ulaşılamamıştır.

\section{Sonuç}

Musannifek'e dair bilgilerimiz büyük ölçüde Taşköprîzâde'nin eş-Şekāik adl1 eserine dayanmaktadır. Taşköprîzâde, Musannifek'in Tuhfetü'l-vüzera adlı eserinde kendi otobiyografisini verdiği kısmı alıntılamış, ayrıca kaynağı belli olmayan bir takım rivâyetleri de eklemiştir. Bu rivayetlerin büyük kısmı sorunludur. Tıpkıbasımı yapılan nüshanın inceleme kısmının Musannifek ile ilgili bölümleri de bu ve benzer tahkik edilmemiş rivâyetlere dayanmaktadır.

Yaşam serüvenine Bistâm'in Şahrûd köyünde başlayan Musannifek'in; Herat, Karabağ, Tebriz, Meram, Larende, Bursa, Ebher, Erzincan, Tokat, Dımaşk, Mekke, Medine, Hayrabolu ve Bosna'ya seyahatlerinin olduğunu biliyoruz. Yaşamının büyük bir kısmını Konya ve Edirne'de geçiren Musannifek'in İstanbul'a geldiğine dair henüz kesin bir bilgiye rastlanmamıştır.

Musannifek'in eserlerini İstanbul Kütüphanelerine veya Sahn-1 Semân medreselerine vakfettiğine dair de kendine ait bir kayıt yoktur. Kendisine ait vakıf kayıtlarında müellif eserlerini ulemâya ve fudalâya vakfettiği görülmektedir.

Süleymaniye Kütüphanesi, Murad Molla, no. 577'de birlikte ciltlenmiş eserlerden biri Abdülazîz Buhârî’ye ait olan et-Tahkik adlı eseri; ikinci eser ise Sahih-i Buhârî adlı kitaptır. Abdülazîz Buhârî'nin et-Tahkik adlı eserinin zahriyesinde Musannifek'e ait temellük kaydı ve mühür bulunmaktadır. Bu iki eserin ne zaman, nasıl ve neden bir araya getirildiği soruları henüz cevaplanabilmiş değildir. Aynı numarada bulunan Sahîh-i Buhârî̀nin (tıpkıbasımı yapılan kısmın) nüshasının üzerinde ise Musannifek'e ait herhangi bir kayıt bulunmamaktadır.

Musannifek'in temellükü olan Câmiü 's-sahîh/Sahîh-i Buhârî̀nin dört nüshas1 (dört cilt) şu an Süleymaniye Kütüphanesi, Fatih, no. 1089, 1090, 1091 ve 1092'de bulunmaktadır. Mezkûr nüshalar Musannifek tarafından okunmuş, notlandırılmış 
ve 873/1468 senesinde vakfedilmiştir. Ancak benzer durum tıpkıbasımı yapılan Murad Molla no. 577 nüshası için söz konusu değildir.

Tıpkıbasımı yapılan nüshanın inceleme kısmındaki Musannifek'in İstanbul'a geldiği, eserlerini Sahn-1 Semân medreselerine vakfettiği iddiaları ikinci el kaynak rivayetlere dayanmaktadır ve müellifin kendi kayıtlarından hareketle şu ana kadar doğrulanamamıştır. Buradan hareketle Murad Molla nüshasının da Musannifek tarafından İstanbul'a getirildiği ve vakfedildiği iddiasını doğrulayacak bir kayıt bulunmamaktadir.

İlgili neşirde Musannifek ile ilgili kesin bilgiye dayanmayan konularda "Eser Musannifek eliyle vakfedilmiştir", "eser Musannifek eliyle İstanbul' a gelmiştir” gibi kesin yargı cümleleri yerine, ihtimal içeren cümleler kurulması daha isabetli ve mevcut kayıtlara uygun olurdu. Henüz kesinlik kazanmamış hipotetik (zannî) bilgilerin kesin bilgi şeklinde sunulmasının konu üzerinde yapılacak yeni araştırmaların önünü kapatması muhtemeldir. Bu da özellikle tarihi araştırmaları gerektiren çalışmalarda, mevcut bilgilerin sunumunda daha titiz ve özenli olmayı gerektirmektedir.

\section{Kaynakça/References}

Abdülaziz b. Ahmed el-Buhârî. Keş̧ü'l-esrâr ve hadâiku'l-ebrar. Süleymaniye Kütüphanesi, Fatih, no. 1344 .

Başbakanlık Osmanlı Arşivi (BOA), Bâb-ı Defterî Haremeyn Muhasebesi Sultan Fatih Evkâfi Kalemi Defterleri (Bâb-1 Defterî Haremeyn), 21941-B.

Beğavî Muhyissünne el-Hüseyn b. Mes'ud. Mesâbîhu’s-Sünne. Süleymaniye Kütüphanesi, Fâtih, no. 1186.

Buhârî, Muhammed b. İsmail b. İbrahim. el-Câmiu’s-Sahîh. Süleymaniye Kütüphanesi, Fatih, no. 1092.

el-Câmi 'u's-Sahîhu'l-Müsnedü'l-Muhtasar Min Hadîsi Rasülillâh Sallâllâhu Aleyhi ve Sellem, Sahîh-i Buhârî. Tıpkıbasım, Süleymaniye Yazma Eser Kütüphanesi, Murad Molla, no. 577'de Kayıtlı Nüshanın Tıpkıbasımı, (inceleme-fihrist), inceleme: Muhammed Mücîr el-Hatîb, Arafat Aydın, İstanbul: Türkiye Yazma Eserler Kurumu Başkanlığı Yayınları, 2018.

Erünsal, İsmail E.. “Osmanlılarda Kütüphaneler ve Kütüphanecilik Tarihi Gelişimi ve Organizasyonu. İstanbul: Timaş Yayınları, 2015.

Hâce Parsa Muhammed b. Muhammed. Faslu'l-Hitâb. Süleymaniye Kütüphanesi, Fâtih no. 2753. Hacı Hasan-zâde. Fâtih Kütüphanesi Katalogu. Topkapı Sarayı Müzesi Arşivi, no. 9559.

Hoca Sadeddin Efendi. Tâcü't-Tevârîh. İstanbul: Tabhane-i Amire, 1279.

İbn Esir Mecdüddîn Mübarek b. Muhammed. Câmiu'l-usûl min ehâdisi'r-rasul. Süleymaniye Kütüphanesi, Fâtih, no. 722.

İbn Hâcib Cemaleddîn Osman b. Ömer. Muhtasaru İbn Hâcib fî usûli'l-fikh. (Müstensih: Yahya b. Muhammed), Süleymaniye Kütüphanesi, Çorlulu Ali Paşa, no. 169.

Karaver, Ümit. Musannifek'e Nisbet Edilen 'Avâmil-i Atîk'Şerhi (Tahkik ve Tahlil). İstanbul: Kitâbi, 2019. 
Mehmed Mecdî Efendi. Hadâiku'ş-Şekāik. Tercüme ve Zeyl-i Şekāik-i Numâniyye, haz. Abdülkadir Özcan İstanbul: y.y., 1409/1989.

Musannifek, Şeyh Alî b. Muhammed eş-Şâhrûdî el-Bistâmî. el-Muhammediye fi 't-tefsir fi tefsiri'lFâtiha (Kitâbü'ş-Şifâ). Beyazıd Kütüphanesi, Veliyüddin Efendi, no. 261.

Musannifek. Hallü'r-rumûz ve keşfu 'l-kunûz. (Müellif Hattı) Süleymaniye Kütüphanesi, Fâtih, no. 2611.

Musannifek. Mülteka'l-bahreyn/Kitâbü'ş-Şifâ. Süleymaniye Kütüphanesi, Fatih, no. 636.

Musannifek. Şerhu'l-Hidâye. (Müellif Hattı) Süleymaniye Kütüphanesi, Fâtih, no. 1965.

Musannifek. Şerhu'l-Lübâb. (Müellif Hatt1), Süleymaniye Kütüphanesi, Fâtih, no. 5004.

Musannifek. Tuhfetü'l-vüzerâ. Süleymaniye Kütüphanesi, Ayasofya, no. 2855.

Musannifek. Tuhfetü'l-vüzerâ. (Müellif Hattı) Topkapı Sarayı Müzesi Kütüphanesi, Emanet Hazinesi, no. 1342 .

Öngören, Reşat. Tarihte Bir Aydın Tarikatı Zeyniler. İstanbul: İnsan Yayınları, 2003.

Taşköprîzâde. Ebü’l-Hayr İsâmuddîn Ahmed Efendi. eş-Şekāiku'n-Nu 'mâniyye fí 'ulemâi'd-devleti'l'Osmâniyye, : Süleymaniye Kütüphanesi, Hasan Hüsnü Paşa, no. 835M.

Taşköprîzâde. eş-Şekāiku'n-Nu 'mâniyye fí 'ulemâi'd-Devleti'l- 'Osmâniyye. Beyrut: Daru'l-Kitabi'lArabî, 1395/1975.

Taşköprîzâde. eş-Şekāiku'n-Nu 'mâniye fì 'ulemâi'd-devleti'l- 'Osmâniyye. thk: Ahmed Subhi Furat, İstanbul Edebiyat Fakültesi Basımevi, 1405/1985.

Yaşaroğlu, M. Kâmil. “Musannifek”, TDV İslâm Ansiklopedisi, XXXI (İstanbul 2006) s. 239-240.

Zemahşerî. Carullah Mahmud b. Ömer. el-Keşşâf an hakāiki t-tenzil, (Müstensih: Musannifek, Konya, 860) : Süleymaniye Kütüphanesi, Fâtih, no. 393.

Zemahşerî. el-Keşşâf. Süleymaniye Kütüphanesi, Fâtih no. 386.

Zeydânî, Mazharuddîn Hüseyn b. Mahmud. el-Mefâtîh fi Halli’l-Mesâbîh. Süleymaniye Kütüphanesi, Fatih, no. 5360. 
